\title{
THE STRUGGLE OVER THE EMPLOYMENT CONTRACTS ACT 1987-1991
}

\author{
Sarah Heal \\ Otago University
}

\begin{abstract}
The introduction of the Employment Contracts Act was opposed by many workers and has subsequently been condemned by a number of organisations. This paper attempts to address the question of why, given the widespread opposition to the proposed legislation, a general strike did not occur in an attempt to defeat the Employment Contracts Bill. It is argued that the failure of the leadership of the Council of Trade Unions to take up the call for a general strike and then to lead such an action was a key factor in the enactment of the Employment Contracts Act. Explanations for the unwillingness of the Council of Trade Unions to lead a general strike are provided both by the thesis of bureaucratic conservatism and by the policy approach adopted by the Council of Trade Unions in the preceding years.
\end{abstract}

In the aftermath of the enactment of the Employment Contracts Bill many New Zealander's were bitter and confused as to how such a fundamentally anti-union piece of legislation, opposed by the majority of the population, came to be introduced. This paper represents an attempt to address that issue. It will be argued that it was the capitulation of the trade union leadership to the wishes of employers and the National Government that led to the enactment of the legislation. Specifically, the failure of the Council of Trade Union's (C.T.U.) leadership to call for and lead a general strike is cited as a major conjunctural factor in the passage of the Bill. Other factors include the economic crisis, the shift in the balance of power between employers and unions and the rise of the New Right.

It is important to examine why the C.T.U. leadership neglected to respond to the wishes of its members. This is explained with reference to the policy approach adopted by the C.T.U. in the years preceding the introduction of the Employment Contracts Bill and with reference to the theory of bureaucratic conservatism.

\section{The thesis of bureaucratic conservatism}

A key restriction on the ability of trade unions to work effectively in the interests of their members is to be found within the unions themselves. Union officials tend to display a contingent conservatism. ${ }^{1}$ This conservatism centrally involves a commitment by union officials to the established procedures of conflict resolution. This usually entails emphasising the role of negotiation in order to successfully conclude disputes. For this reason union officials are often concerned that industrial action does not accelerate to a point where they no longer have control.
Their conservatism is contingent because they are, to varying extents, under pressure to respond to their rank and file union members and also under pressure to respond to the wishes of employers and the government. ${ }^{2}$ The ability of union officials to manipulate the workplace situation is usually dependent upon the apathy or inexperience of most of their members. Where there are militant members within a union these are often not numerous or influential enough to sway the majority. ${ }^{3}$

There are two broad reasons for the conservatism of full time union officials. Firstly, they have their own interests, distinct from those of the rank and file. Secondly the concrete circumstances of trade union officialdom tend to cause conservatism. Trade union bureaucrats act as intermediaries between capital and labour. Usually, officials are aware of their own role and interests and recognise that they are dependent on trade unionism for their livelihood. Thus they have no interest in jeopardising the status quo. ${ }^{4}$

Trade union officials also develop conservative tendencies as a result of the work they do. The nature of their work requires that they be set apart from the ordinary members of the union. They become isolated both geographically and ideologically. It therefore becomes very difficult for officials to reflect the views of their members. ${ }^{5}$ Often they enjoy greater job security and higher wages than rank-andfile union members. ${ }^{6}$ Trade union officials will not usually agree to tactics that will weaken their position within the trade union bureaucracy. Thus strike action is often opposed where it threatens the existence of the union or the maintenance of union funds. Whilst union officials may wish to use the threat of strike action as a tool to influence an employer, they often do not wish to see this power 
actually unleashed. ${ }^{7}$

In order to strengthen their position union officials emphasise negotiation and compromise. Rank-and-file members easily become dependent upon what they perceive to be the experience and expertise of their officials. ${ }^{8}$ Finally, there is usually a lack of accountability where trade union officials are concerned. Many are appointed rather than elected. Furthermore, it is common for union bureaucrats not to be subject to any regular, effective accountability. This limits the extent to which it is possible to keep their conservatism in check. ${ }^{9}$ The thesis of bureaucratic conservatism helps us to understand the course of the struggle over the Employment Contracts Act

\section{The policy approach of the C.T.U.}

Since its inception in 1987 the C.T.U. has adopted a conciliatory approach towards both the government and employers. Probably the most obvious example of this prior to the struggle over the Employment Contracts Bill was the manoeuvring that occurred around the Compact. The Compact was a proposed agreement between the Government, employers and unions initially and later between the Government and unions only. In its final form, the compact, entitled the 'Agreement for Growth' provided for a ceiling on wage settlements in return for a reduction in interest rates and the promise of talks between representatives of Government, unions and business.

Whilst it is not possible here to discuss this issue in depth, there are a number of aspects of the negotiation that should be noted. The first problem area was the fact that the C.T.U. pamphlet 'Towards a Compact' was distributed only among trade union officials and not the rank-and-file. Thus, as early as March 1988, there was an absence of communication between the C.T.U. leadership and its members. ${ }^{10}$ At a meeting in Christchurch on May 24 eighty union officials and job delegates requested that there should be more information available about the Compact plus the opportunity for open debate about the subject. In Waikato, Bill Andersen and other officials from the Drivers Union refused the local anti-Compact group the opportunity to address stop-work meetings. This is evidence of the unwillingness of the C.T.U. leadership to allow open debate. ${ }^{11}$

In mid-1989, the Northern Distribution Union held stopwork meetings at which the Compact was discussed. A resolution of limited support for the Compact, which had been passed at the N.D.U. delegates conference, was put to these stop work meetings The resolution was carried on a show of hands. However, there is some doubt as to whether the chair's decision was, in fact, accurate as a number of people who were present believe that the majority of those who voted were actually opposed to the Compact. ${ }^{12}$

The refusal of the C.T.U. to allow open debate continued with the ruling of the C.T.U. vice-president, Angela Foulkes, that the group, Trade Unionists Against the Compact, would not be permitted to present a petition to the C.T.U. conference. It was argued by the C.T.U. National Executive that such a petition would 'fall outside the C.T.U. constitution'.13

The decision to discard the December 20th Compact proposal occurred without consultation with the union movement. The C.T.U. National Council meetings on March 14 and March 15 did not endorse these changes which had been decided upon by the C.T.U. leadership. ${ }^{14}$ On April 3, the C.T.U. conference was held at which two resolutions were put to the meeting. The first was proposed by the C.T.U. national executive which called for cooperation between the C.T.U. and the Government. The second was proposed by the Service Workers Federation. It favoured a campaign aimed at defeating the economic agenda of the Business Roundtable. During the conference lunchbreak it was arranged that the C.T.U. National Executive would support the Service Workers Federation proposal in return for the Service Workers Federation support for the National Executive's Compact resolution. 15

In July 1990 five officials from the C.T.U. National Executive began meeting regularly with Helen Clark, then the Labour Government's Minister of Labour. Of the five officials, Ken Douglas, Angela Foulkes and Ron Burgess were to be permanently involved in negotiations with the Compact Council. The remaining two officials were to be chosen by the first three from the C.T.U. National Executive. Furthermore, the identity of these officials were not disclosed to the C.T.U. National Council, nor did the delegation report back to the National Council regarding what matters were discussed. ${ }^{16}$

The evidence suggests a measure of secrecy in the approach of the C.T.U. leadership to the Compact. Similarly, it seems likely that truly open debate was discouraged in favour of statements that merely supported the Compact. There can be no doubt that the C.T.U. leadership was negligent in its failure to communicate effectively with its members. They declined to fight the right wing policies of the Labour Government preferring instead an offer of minimal consultation in the policy-making process. The importance placed by the C.T.U. on the Compact and, indeed, its approach towards securing the Compact is indicative of bureaucratic conservatism.

\section{The struggle over the Employment Contracts Act}

In my MA thesis, "The Struggle For and Against the ECA 1987-1991" a theoretical framework based on Marxist industrial relations theory is established. This is used to analyse the empirical evidence. An historical framework is also created within which to locate the struggle. Three chapters are then devoted to the case study. Chapter Three outlines the industrial relations environment from which the Employment Contracts Bill emerged. This deals with the nature of industrial relations under the Labour Relations Act. Chapter Four examines the period immediatley 
prior to the introduction of the bill. In Chapter Five the actions of the government, unions and employers in the period between the introduction of the bill and its enactment are considered. In the rest of this paper, I focus on the complex union debate over the nature of appropriate action to take in opposition to the bill. Particular emphasis is given to the CTU's Special Affiliates Conference.

Pressure for a general strike was developing throughout the beginning of 1991. Early in April up to 1,000 members of the Northern Drug and Chemical Union held a stopwork meeting at which they called for a national twenty-four hour strike on May Day. ${ }^{17}$ On 5 April the New Zealand Herald had stated that the calls for a general strike would be discussed at the nextC.T.U. national conference. Among the groups that had called for a national strike, according to the Herald, were the distribution workers, clerical workers and cleaners. The response of the C.T.U. industrial officer was to say that the Council was unsure of the extent of the support for a national strike. ${ }^{18}$ Agitation for a general strike is reflected in the debate over whether to oppose the Bill (try to make changes to the proposed legislation) or whether to defeat the Bill (take action designed to make the Government retract the proposed legislation).

There were widespread calls for effective leadership of the union movement. On 21 April, at a special branch meeting, Nelson P.S.A. members passed a unanimous vote of no confidence in the P.S.A. president, Sue Piper. This was in response to the inaction of the P.S.A. on resolutions sent to it by the Nelson branch and by the unwillingness of the P.S.A. to provide effective leadership for those who wished to defeat the Bill. The P.S.A. told the Nelson branch that they would only sanction a one-day strike and cautioned their members regarding patient welfare - a reference to P.S.A. members who were employed at Ngaw hatu psychiatric hospital. ${ }^{19}$ On 15 April, members of the Canterbury branch of the P.S.A. also passed a motion of no confidence in the P.S.A. president. Again, this was a result of the failure of the P.S.A. to respond positively to calls from the membership for a general strike. 20

The P.S.A. national executive was not the only body of trade union leaders to have upset its members. On 4 April, members of the Engineers Union at the Amotts biscuit factory in Auckland passed a vote of no confidence in Engineers Union national secretary, Rex Jones. The reason given for this vote was Jones' "lack of leadership in the fight against the Employment Contracts Bill and his apparent acceptance of the Bill". They were also disappointed by the failure of the Engineers Union leadership to join them in a march on 10 April against the Employment Contracts Act. Furthermore, dislike was expressed for the part that Rex Jones had played in the signing of the Compact between the Labour Government and the C.T.U. national executive. ${ }^{21}$

In Hokitika on 15 April Ken Douglas was questioned as to why the C.T.U. leadership had declined to lead a general strike in response to the Employment Contracts Bill. Douglas said that they would be "waiting forever" for him to give the call for a general strike. He continued, "there has to be an answer other than just leading a protest parade ${ }^{n} .22$ This remark was widely reported in the national media, providing further evidence of the C.T.U.'s reluctance to lead a general strike.

Support for a general strike continued to build steadily. On 12 April the executive director of the Nurses Association, Gay Williams, announced that nurses in the public sector had voted in favour of a strike. This strike was to be a one day strike, to occur on 29 April. ${ }^{23}$ On April 14, Pat Kelly, secretary of the Cleaners, Caretakers and Security Officers Union speculated that there was a sixty percent chance of there being a general strike. Kelly said that whilst a number of unions had not decided upon a definite policy position they have stated that "if such a call is made they guarantee their members will support it". Kelly added that if the outcome of the special affiliates meeting on 18 April was a call for a general strike then he was confident of an overwhelming response from the country. ${ }^{24}$

The speculation of Mr. Kelly regarding support for a general strike was echoed by Peter Monteith, retail secretary of the Northern Distribution Union. Monteith based his estimate of support on the high attendance at stopwork meetings by his members. He said that meetings of shop workers held throughout the northern industrial district were attracting approximately two or three times the normal attendance and that the overall theme was one of overwhelming support for action against the Employment Contracts Bill. According to the New Zealand Herald, support for a strike had also come from "delegates from other unions whose management have not publicly backed the idea". However, statements made by Ken Douglas appear to contradict the assertions made by various union leaders and delegates regarding the support for a strike. Douglas stated that whilst some unions were keen to take strike action against the Employment Contracts Bill few had given their unreserved support for a twenty-four hour or a forty-eight hour stoppage. In describing the C.T.U. role in such an action Douglas said that the C.T.U. did not have the power to call a strike and instead was looking at ways of changing public attitudes to the legislation. 25

\section{The C.T.U. special affiliates conference (18 April)}

At the special C.T.U. affiliates conference on 18 April initial debate centred around the C.T.U.'s national executive's resolution, particularly clause $C$. Clause $C$ called for affiliates to "participate in a national day of activity on April 30, ranging from lunchtime meetings to a duration of twenty-four hours". Speaking in favour of the national executive resolution, Douglas said: "we need to be clear about what the resolution is for. It needs to be demonstrably achievable, both nationally and in the regions. Members come from different positions. What's important is what they are prepared to do not what they can be con- 
scripted to do. ${ }^{26}$

In response to the call for a general strike Douglas said that "we must not confuse uniformity with unity". Pat Kelly answered Douglas's statement with the assertion the "there have been calls for a general stoppage, calls coming from the floor. I believe it is being sought by working people now. We can't ignore those calls".27

After various arguments both for and against a general strike, Rick Barker of the Service Workers Federation moved an amendment calling for a twenty-four hour national stoppage on 30 April. Barker said that: "It is quite clear from all our stopwork meetings that there is support for a one-day stoppage. Each affiliate to the Service Workers Federation has had unanimous calls for a twentyfour hour strike. There must be a specific response to that firm call from workers. ${ }^{28}$

He continued, saying that members of the Service Workers Federation have said that "when they do it they want to do it together. They want a collective veil drawn over them because their employers can see when they are acting alone". 29

Maurice Ward of the Tramways Union had earlier moved an amendment to the resolution of the C.T.U. which called for the C.T.U. national executive to "organise a campaign of mass action to oppose the Employment Contracts Bill until it is withdrawn or defeated". Tony Wilton of the Journalists and Graphic Process Union supported this resolution. Thus, debate later in the conference centred around the calls for a general strike..$^{30}$

Card voting occured on the Service Workers Federation amendment and the amendment was defeated by 250,122 to 190,910 . According to The People's Voice, those unions which voted against a general strike included the Engineers Union, The Public Service Association, Post Primary Teachers Association, Nurses Association, Post Office Union, Education Institute and the Financial Sector Union. ${ }^{31}$ This is supported by evidence collected in interviews. Malcolm Blair of the Communication and Energy Workers Union confirmed that the Post Office Union voted against the amendment and that most of the major unions were not in favour of the amendment. Steph Breen of the Nurses Organisation (previously the Nurses Union and Nurses Association) said that there was never a call for a national strike by the C.T.U. and so the union could not say whether or not the members supported a national strike. However, it is likely that the members of the Nurses Union did indeed support a national strike. For example, in Dunedin alone on 10 April 600 votes out of 650 cast by health workers favoured a one day strike from $3 \mathrm{pm}$ April 29 to $3 \mathrm{pm}$ April $30 .{ }^{32}$ It is plausible that such figures reflected a nationwide trend. At the special C.T.U. affiliates conference the Nurses Union voted against the Service Workers Federation Amendment. John Ryall said that it was mostly the state unions that voted against the amendment and the private sector unions that voted for the amendment. McKeefry of the Engineers Union said that the P.S.A., the Nurses Union, the education unions, the Post Office Union and the Engineers Union all voted against the amendment. Colin Davies of the P.S.A. confirmed that the P.S.A. voted against the amendment as did the Engineers Union. The call for a general strike was also supported by some of the unions outside the C.T.U.. These included the Seafarers Union and the Building Trades Union. 33

Many of the trade union officials who voted against a general strike were also voting contrary to the wishes of their members. For example, $87 \%$ of Nurses Association members had voted for a twenty-four hour stoppage. ${ }^{34}$ Similarly, even where workers were not balloted, high attendences at stop-work meetings should have indicated to union officials that the issue of a general strike should, at least, have been discussed with their members. This negligence can be explained by the thesis of bureaucratic conservatism. Trade union officials have a vested interest in the negotiation process. In this situation, therefore, the trade union bureaucracy sacrificed its members wishes in exchange for minimising the risks of destruction or disturbance to the C.T.U. structure and capabilities.

The result of the C.T.U. affiliates conference immediately caused division within the union movement. At the 2 May meeting of the Canterbury C.T.U. delegates from various unions reported that the failure to call for a general strike had divided their members. Dion Martin, organiser for the Distribution and General Workers Union also believed that people felt very strongly about the result of the C.T.U. affiliates conference. Furthermore, he stated that if the decision had been made on the basis of one union one vote then the general strike amendment would have been carried. 35

Douglas stated, after the meeting, that the decision not to hold a twenty-four hour general strike did not indicate that there was any division or dissent within the union movement. Mr Birch gave a positive response to the decision of the C.T.U.not to hold a general strike. Birch said that it was "obvious to all New Zealanders that strike action could not be justified". 36

\section{The nationwide day of action}

Around the country, various unions decided that their contribution to the 30 April day of action would be to take strike action of some form. The Auckland C.T.U. called for a five-hour regional strike from midday Tuesday 30 April. District president Bill Andersen predicted that the march in Auckland on the day of action would be one of the biggest ever seen in the city. He said that the reason for only calling for a half-day regional strike was to obtain the maximum number of people on the march for a minimum stoppage of work. However, he conceded that some unions were recommending to their members that strike action be taken for a whole day. 37 
The Building Trades Union voted for a three-day strike to be held on the 29 and 30 April and on 1 May. The action would be in protest both at the collapse of their award and against the Employment Contracts Bill. Ashley Russ, secretary of the Building Trades Union stated that "in continuing their demands for the abolition of travelling time and an extension of the ordinary hours of work beyond an eight-hour day, the employers are signalling their intention to end the national award system". 38 The decision to hold a three-day strike was supported by over ninety percent of the Building Trade Union's members. Support for a general strike, if the C.T.U. called for one, was almost 100 percent of the Building Trade Union's members. 39

Health workers were unable to take the twenty-four hour strike that their members had favoured because the Labour Court granted injunctions to the Auckland and Otago area health boards to prevent certain workers from withdrawing their labour. 40

At Kinleith, pulp and paper workers decided against a twenty-four hour stoppage after New Zealand Forest Products began legal action. Instead, they voted for a three hour strike. In Kawerau, workers at the Tasman Pulp and Paper Mill voted to hold a twenty-four hour strike and the Hawkes Bay pulp mill workers voted for similar action. Meatworkers voted to strike for twenty-four hours. Govemment department staff participated in various actions ranging from a twenty-four hour strike to work bans. ${ }^{41}$

At various stopwork meetings feelings among teachers were running high regarding appropriate action for 30 April. The Auckland branch of the Post Primary Teachers Association passed an amendment which called for a twenty-four hour strike. This was despite a proposal by the executive that the teachers limit themselves to a five-hour stoppage. Len Richards of Nga Tapuwae College accused C.T.U. president Ken Douglas of "working for the Government in resisting the pressure for a general strike". He stated that "national delegates of his own union had no right to vote against a general strike along with other state sector unions" at the special C.T.U. affiliates conference on 18 April. A national negotiator for the P.P.T.A., Mark Barrow responded that a strike which received seventy percent support would be seen as a failure by the media and the government but a national day of action with similar support would be seen as successful. ${ }^{42}$

The day of action was a huge success with sixty thousand people marching against the Employment Contracts Bill. Many marchers took up chants in favour of a general strike. In Auckland a rally was held at Aotea Square, chaired by Bill Andersen. The efforts of Peter Hughes, chairman of the Auckland branch of the Communist Party, to put forward a resolution for a general strike were unsuccessful as union officials physically prevented him from reaching the microphone. Andersen put forward a resolution which 'condemned' the Bill and welfare cuts and called for future union action. 43
On 1 May a huge May Day rally occurred despite the efforts of the C.T.U. The leaders of the Auckland C.T.U. and the C.T.U. national office wanted the May Day committee to hold their march on 30 April and have a celebration on 1 May to commemorate May Day. ${ }^{44}$

Two days later, on 3 May Parliament passed the Employment Contracts Bill by a forty-three to twenty-four majority. 45

\section{Conclusion}

There are a number of ways in which the nature of trade union officialdom is reflected in the New Zealand experience over the Employment Contracts Act. A number of trade union officials emphasised the importance of the continuity and credibility of their trade union at the expense of mass struggle. For example, in defending the decision of the Nurses Union to oppose strike action, Steph Breen stated that: "There's a difference between idealism and pragmatism and realism; about who's got their feet on the ground and who's just standing up waving the banner. If you're going to say we're going to do this you've got to be able to deliver or otherwise your credibility goes down the tubes. 46

Similarly, John McKeefry, of the Engineers' Union, in discussing the strategy that his union adopted in response to the Employment Contracts Bill states that: "They (National) were going to do it, we'd best not enrage them further, we'd best not take that option and what we'd best do is to prepare a very well-researched submission arguing for the alternative which is the high wage, high skill economy and arguing that we needed to have a coordinated labour relations policy across the country to ensure that standards are kept up and that the emphasis is not on shortterm wage cutting solutions but investing in training and skills and things like that and we'd best educate our own employees. $^{n 4}$

The leadership of the C.T.U. in particular placed considerable emphasis on compromise and upon their negotiating ability. This is evidenced in the decision of the C.T.U. to mount a protest campaign aimed at achieving major modifications to the bill rather than the abolition of the bill entirely. Similarly, in his speech to protesters in Auckland in April 1991, Bill Anderson stressed that if the protest activities were not sufficient to persuade the government to withdraw the bill then the unions would have to try for the "best possible agreement". Finally, the fact that the C.T.U. adopted the 'oppose the bill' line rather than the 'defeat the bill' line favoured by many is an indication that they were more interested in negotiation than in struggle.

There were three specific ways in which union leaders contributed to the government's ability to pass the Employment Contracts Act with very little difficulty. Firstly, the C.T.U. failed to call for a general strike. This was despite the clear majority support for a general strike from rank-and-file unionists and, indeed, from many branch 
organisations affiliated to the C.T.U., for example, the Canterbury branch of the P.S.A. Indeed, Ken Douglas indicated, in his speech to protestors at Hokitika on 15 April, (before the Special Affiliates Conference of 18 April) that the C.T.U. was unwilling to lead a general strike.

The leadership of many unions were out of step with their members' wishes when they block voted against a general strike at the C.T.U. Special Affiliates Conference on 18 April. These unions included the P.S.A., the Nurses Union, the Engineers Union and theP.P.T.A.Some have defended their actions on the grounds that they did not ballot their members and so they were unsure of the support for strike action - for example, the Engineers Union and the Nurses Organisation. The level of support for strike action both on the streets and at regional stopwork meetings indicate that such union leaders would have been well aware of the general feeling regarding strike action and that in fact it was this awareness that prevented them from balloting members because they knew what the result would be.

Finally, the C.T.U. acted negligently when it refused to provide any centralised leadership. It was decided that action should be organised on a region by region basis. As the umbrella body for unions, the C.T.U. abdicated its responsibility when it refused to provide national coordination for regional activities. Furthermore, when regional action contradicted the official stance, as it did in Canterbury, the C.T.U. took measures designed to sabotage this action thus contravening its own stated decision regarding regional autonomy.

The scale of the various protest activities and meetings described above indicate that there clearly was majority support for strike action among workers. That there was widespread support for strike action is shown by the vast numbers of people who were involved in protest marches in early 1991. Similarly the high attendances at stopwork meetings illustrate the depth of feeling in the country at large. Statements by government ministers indicate that there was an awareness of this among those people pivotal to the introduction of the Bill. For example, Bolger publicly attacked the union movement and Birch responded angrily to the introduction of some closed shops. Finally, Max Bradford even indicated that some changes to the legislation might be necessary in the face of such strong opposition. ${ }^{48}$ The blame for the absence of a general strike should therefore be laid at the feet of the union leaders who declined to organise an action which their membership wanted. A general strike could have defeated the Bill protest activities alone were never going to achieve that goal.

\section{Future research}

This paper answers some questions about this period in New Zealand's labour history but also indicates a need for many others to be asked. Such concems might include the nature of any industrial action that could be taken. This would encompass its likely effects, sustainability and the extent to which it would be both nationwide and across a variety of industries.

One potential area for further research is an in depth analysis of the government concerns about the struggle over the Employment Contracts Act. Such concerns might include the nature of any industrial action that could be taken. This would encompass its likely effects, sustainability and the extent to which it would be both nationwide and across a variety of industries. This would require access to the appropriate ministerial documents.

Similarly, it would be interesting to examine the concerns of the New Zealand Employers Federation and the New Zealand Business Roundtable about the struggle over the Employment Contracts Act at the time. In other words, did they feel that the charges embodied in the proposed legislation were under threat in the early months of 1991 ?

A further potential area of research could be a comparison of the influence of the C.T.U. leadership within the union movement both before and after the Employment Contracts Act. This could incorporate an analysis of the effect upon the C.T.U. of its failure to lead a general strike.

Finally, it could be valuable to compare the introduction of the Employment Contracts Act with efforts to introduce enterprise bargaining in Australia and, indeed, in other advanced capitalist countries (see paper by Neilson in this volume).

\section{References}

Bramble T. 1993 "The Contingent Conservatism of Full Time Union Officials", unpublished PhD Thesis, La Trobe University, Melbourne

Clarke T. \& Clements L. (eds.) 1978 Trade Unions Under Capitalism, Harvester Press, Sussex.

Cliff T. \& Gluckstein D. 1986 Marxism and Trade Union Struggle, Bookmarks, London.

Deeks J. \& Perry N. (eds.) 1992 Controlling Interests, Auckland University Press, Auckland.

Heal, S. 1994 The Struggle for and Against the Employment Contracts Act, 1984-1991, unpublished MA Thesis, University

Hyman R., 1989 The Political Economy of Industrial Relations, Macmillan, London.

Kelly T., 1989 Trade Unions and Socialist Politics, Verso, London.

\section{New Zealand Herald}

The Peoples Voice 
Otago Daily Times

Roth H., 1987-1991 "The Chronicle", New Zealand Journal of Industrial Relations.

Sandlant R., 1989 The Political Economy of Wage Restraint: The Australian Accord and Trade Union Strategy in New Zealand, unpublished MA Thesis, University of Auckland.

Wilson A., 1991 The New Zealand Council of Trade Unions: History, Structure and Role, BA (Hons) dissertation, University of Otago.

\section{Notes}

1 The bureaucratic conservatism thesis is not universally accepted. For a discussion of criticisms of this thesis see the paper by Brian Roper in this volume. See also T. Bramble, Chapter 1 and J. Kelly, 1989. Other discussions of the thesis of bureaucratic conservatism include: T. Cliff \& D. Gluckstein, 1986: 21-34; J. Eldridge, "Trade Unions and Bureaucratic Control" in T. Clarke\&L. Clements (eds.), 1978:175-183 and R. Hyman \& R. Fryer, "Trade Unions: Sociology and Political Economy" in T. Clarke \& L. Clements (eds.), 1978:152-174.

2 T. Bramble, 1993: xiv-xv.

3 Ibid., pp.18-19.

4 Ibid.,pp.24-28.

5 T. Cliff \& D. Gluckstein, 1986: 27.

6 J. Kelly, 1989:151.

7 J. Kelly, 1989:153.

8 R. Hyman, 1989247.

9 J. Kelly, 1989:151.

10 The Peoples Voice, 6th March 1989.

11 Ibid., 29th May 1989.

12 Ibid, 18th September 1989.

13 Ibid., 18th September 1989.

14 Ibid., 19th March 1990.

15 Ibid., 16th April 1990.

16 Ibid., 23rd July 1990.

17 H. Roth, Chronicle, New Zealand Journal of Industrial Relations, April 1991.

18 New Zealand Herald, 5 April 1991, p. 1.

19 The People's Voice 17 April 1991,p. 24.

20 Ibid., 6 May 1991, p. 8.

21 Ibid., 17 June 1991, p. 10.

22 Ibid., 6 May 1991, p. 24.

23 New Zealand Herald, 13 April 1991, p. 1.

24 Ibid., 15 April 1991, p. 4.

25 Ibid., 18 April 1991, p. 2.

26 The People's Voice, 6 May 1991, pp.3-7.

27 Ibid

28 Ibid

29 Ibid

30 Ibid

31 Ibid

32 Otago Daily Times, Thursday April 11 1991, p. 1

33 Interviews with Colin Davies, P.S.A., 16 August 1993 , John Ryall, Service Workers Federation, 16 August 1993,
Steph Breen. Nurses Organisation, 17 August 1993, Malcolm Blair,Communication andEnergy WorkersUnion 18 August 1993, Dave Morgan, Seafarers Union, 18 August 1993, John McKeefry, Engineers Union, 19 August 1993, Ashley Russ, Building Trades Union, 19 August 1993.

34 See A. Wilson, 1991: 48

35 The People's Voice, 6th May 1991, pp. 6-7.

36 New Zealand Herald, 19 April 1991, p. 2.

37 Ibid., 24 April 1991, p. 3.

38 Ibid., 26 April 1991, p. 3.

39 Interview with Ashley Russ, Building Trades Union,

19 August 1993.

40 New Zealand Herald, 27 April 1991, p. 3.

41 Ibid., 30 April 1991. p. 3.

42 Ibid., 26 April 1991, p. 3.

43 The People's Voice, 6 May 1991, p. 10.

44 Ibid., 6 May 1991, p. 21.

45 H.Roth, Chronicle, New Zealand Journal of Industrial Relations, May 1991.

46 Interview with Steph Breen, Nurses Orgainsation, 17 August 1993.

47 Interview with John McKeefry, Engineers Union, 19 August 1993.

48 Otago Daily Times, Thursday April 11, p. 1.

\section{Author}

Sarah Heal completed her Masters degree in the Departmentof Political Studies at the University of Otago, PO Box 56, Dunedin. 